\title{
Exploration and discovery of a new kimberlite cluster on the Nanuq Property, Western Churchill Province, Kivalliq area, Nunavut
}

\author{
J. Pell, P.K. Holmes, H. Grenon, M.V. Sell and L. Tam \\ Peregrine Diamonds Limited, Vancouver, BC
}

\section{Introduction}

In 2007, a new kimberlite cluster was discovered by Peregrine Diamonds Ltd on the Nanuq property in the eastern Arctic region of Nunavut, Canada. Three diamondiferous kimberlites were discovered by drilling three geophysical anomalies located at the heads of two distinct indicator mineral trains. Two of the kimberlites have surface areas estimated to be greater than five hectares in size, suggesting good tonnage potential for this new district. Future exploration in the area is anticipated to result in additional discoveries. The kimberlites at Nanuq are unique in the eastern Arctic region being the youngest reported to date and the first known occurrenes of crater-facies, volcaniclastic kimberlites.

\section{Regional Setting}

The Nanuq property lies within the Rae domain of the Western Churchill Craton (Figure 1), which is dominated by Neoarchean (2.8-2.5 Ga) amphibolite- to granulite-grade granitoid gneisses and greenstone belts that are overlain by $2.45-1.75$ Ga volcano-sedimentary sequences and intruded by 1.83 and $1.75 \mathrm{Ga}$ granitic suites. The Western Churchill craton was originally subdivided into two distinct crustal blocks, the continental Rae and juvenile Hearne subprovinces.

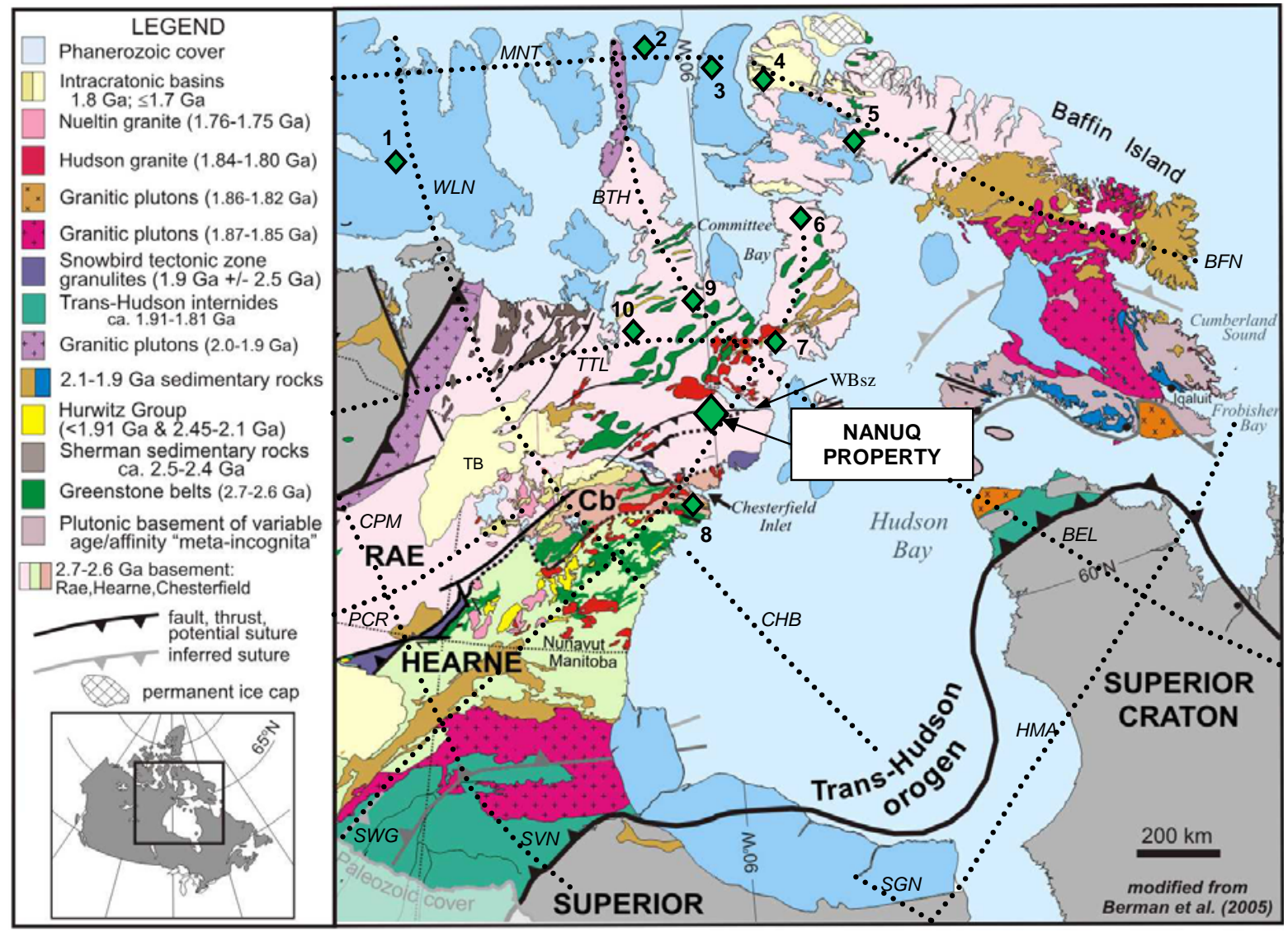

Figure 1. Regional geology of the western Churchill Province and location of the Nanuq property.

$\diamond$ Kimberlite clusters: 1: Victoria Island; 2: Somerset Island; 3: Brodeur Peninsula; 4: Borden Peninsula; 5: Erichsen Lake, Baffin; 6: Melville Peninsula; 7: Repulse Bay; 8: Rankin Inlet; 9: Pelly Bay; 10: Chantry Inlet.

...... Crustal arches (after Card et. al., 1997): BFN: Baffin; BTH: Boothia; MNT: Minto; WLN: Wellington; TTL: Tathlina; CPM: Coppermine; PCR: Peace River; KWN: Keewatin; SWG: Sweetgrass; SVN: Severn; SGN: Saguenay: HMA: Henrietta Maria; CHB: Central Hudson Bay. Abbreviations: Cb: Chesterfield Block; WBsz: Wager Bay Shear Zone; TB: Thelon Basin. 
Recently, a third distinct crustal block, the Chesterfield block (Cb on Figure 1), has been recognized. This block had formerly been considered the northwestern sub-domain of the Hearne. Geochronologucal studies show that the Rae and Chesterfield blocks were amalgamated prior to $\sim 2.61 \mathrm{Ga}$ and the Hearne block was accreted onto them at appoximtely $1.9 \mathrm{Ga}$ (Berman et. al., 2007).

The Nanuq property occurs at the intersection of the Wager Bay Shear Zone, a major east-west structure, and the Keewatin Arch, a major long-lived crustal uplift. The diamondiferous kimberlites at Rankin Inlet, Repulse Bay and on Melville Peninsula also occur along this arch (Figure 1). All kimberlites discovered to date in the Western Churchill region are in the Rae and Chesterfield blocks.

\section{Property Geology}

The Nanuq property is underlain by Archean or Paleoproterozoic paragneisses, Archean orthogneisses and Paleoproterozoic monzogranites. Archean to Paleoproterozoic supracrustal rocks occur in a belt transecting the southern part of the property and as boudinaged layers and lenses within the paragneiss sequences. The supracrustal sequence hosts minor amphibolitic iron-formation, and metamorphosed peridotites and/or komatiites (Panagapko, 2003). The property is located in the vicinity of the Keewatin Ice Divide. Recent studies in the Nanuq area (Dredge and McMartin, 2007; Dredge et. al., 2006) have shown that the till deposits are generally less than $10 \mathrm{~m}$ thick. In the northern part of the property, ice is interpreted to have flowed to the north. In the southern part of the area, ice flowed to the south-southeast.

\section{Exploration and Discovery History}

The Nanuq property was acquired in 2003 to secure an area containing kimberlitic indicator minerals identified by BHP Billiton during reconnaissance till sampling programs. Subsequent till sampling programs defined several southeast trending dispersion plumes dominated by chrome pyrope, eclogitic garnet and chrome diopside with some forsteric olivine and chromite, but no ilmenite. The mineral chemistry showed evidence of sampling within the diamond stability field by the presence of pyrope garnets (both G10's and G9's), and diamond inclusion field eclogitic garnets and chromites. Indicator mineral interpretation is complicated by the presence of abundant nonkimberlitic forsteritic olivine and chromite shed from the ultramafic rocks within the supracrustal sequences. Airborne geophysical surveys were completed over parts of the property in 2003 and 2005.

In 2006, work was focussed on locating the source of a prominent, narrow dispersion plume which contained samples with high counts in all indicator species (Figure 2). A ground magnetic survey at the head of this train identified a strong magnetic low partially within a small, shallow lake. In 2007, a horizontal loop electromagnetic survey indicated the magnetic

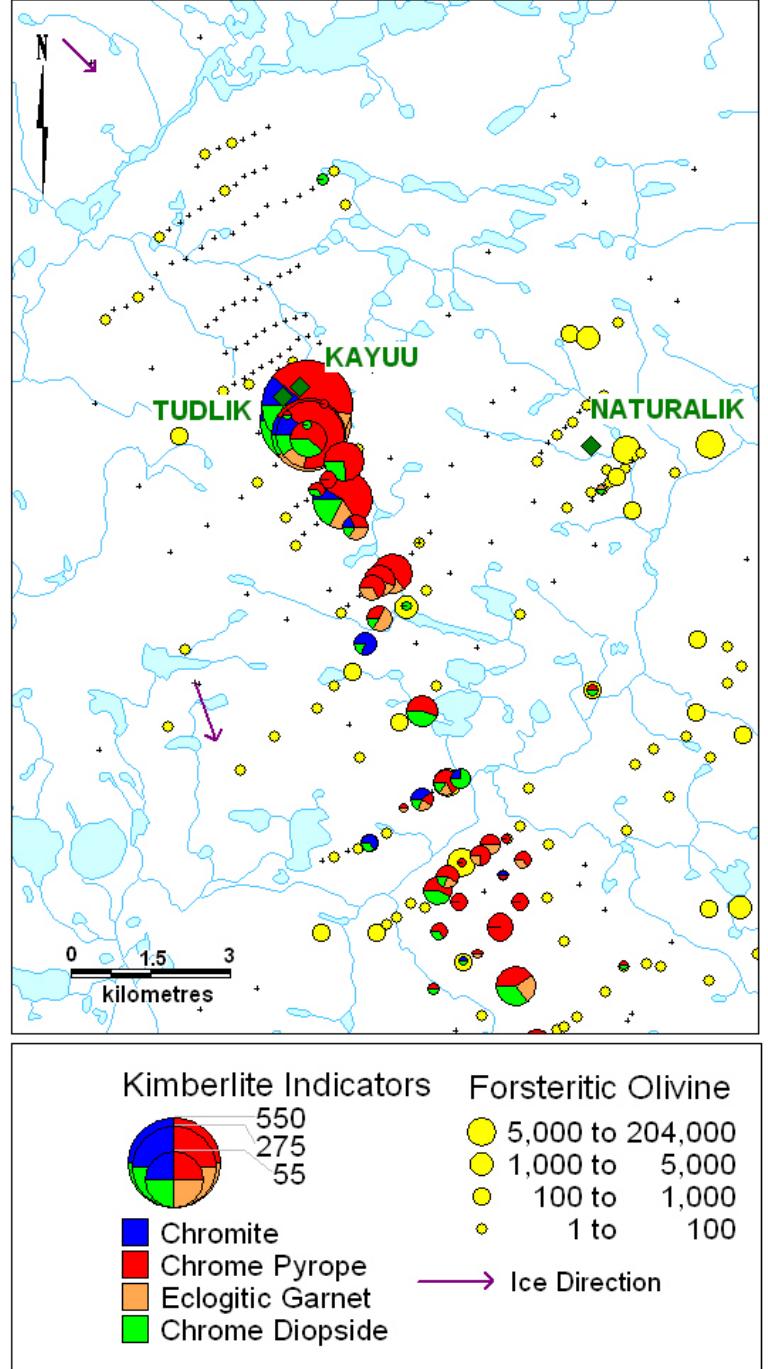

Figure 2: Indicator Mineral Signatures of Kayuu, Tudlik and Naturalik kimberlites.

anomaly also had a slightly offset electromagnetic response on land. Drilling confirmed the presence of two kimberlites in this area: the kimberlite causing the magnetic low target within the lake (Kayuu) and a smaller, land-based kimberlite (Tudlik), associted with a small magnetic low, 200 metres southwest of Kayuu. Another stong magnetic low selected from the 2003 aeromagnetic survey, five kilometres east of the Kayuu and Tudlik kimberlites, was drilled and the Naturalik kimberlite discovered. The usual suite of indicator minerals is absent down-ice of Naturalik - only olivine was found (Figure 2). As abundant non-kimberlitic olivine shed from supracrustal ultramafic rocks is present in the local tills, this train was not originally selected for follow-up. The geophysical target was compelling and was drilled without having a traditional indicator mineral signature.

\section{Characterisits of the Nanuq Kimberlites}

The Kayuu kimberlite has a surface area of at least five hectares and is a very complex body, containing units of resedimented volcaniclastic kimberlite with mud and 
organic fragments, suggesting the presence of unconsolidated sediments at the surface at the time of eruption. Volcaniclastic kimberlite was also identified at Kayuu. Tudlik has an estimated surface area of one hectare and is filled with massive volcaniclastic kimberlite. Naturalik is the largest of the three kimberlites, with an estimated surface area of approximately six hectares. It is filled with coherent kimberlite and subordinate fragmental, volcaniclastic kimberlite. Garnets and other indicator minerals are present in Naturalik; however, in the upper portion of the pipe, the garnets are almost compeletely kelyphitized, which explains the absence of garnets in till samples collected down-ice. Additional details of the geology of the Nanuq kimberlite bodies are presented in Webb et. al., this volume.

Paleomagnetic studies of core samples from Naturalik indicate strong magnetic remanence and negative magnetic polarity, which is consistent with its magnetic signature (strong magnetic low). Uranium/lead radiomentric ages have been determined for perovskites from Kayuu and from Naturalik, giving ages of $70.4 \pm 5.4 \mathrm{Ma}$ and $79.6 \pm 5.2$ Ma respectively (L. Heaman, personal communication, 2008).

\section{Diamond Results}

Samples from the various geoloical units in each kimberlite were analyzed for their diamond content by caustic fusion; combined results are presented in Table 1. Six lithological units were identified at Kayuu (Webb et. al., this volume); 178 stones were recovered from a 177 kilogram sample of a variably fragmental volcaniclastic kimberlite unit, the other five units averaged 0.6 stones/kilogram.

Table 1: Microdiamond Results, Nanuq Kimberlites

\begin{tabular}{|r|r|r|r|}
\hline \multirow{2}{*}{$\begin{array}{c}\text { Sieve Class } \\
(\mathbf{m m})\end{array}$} & \multicolumn{3}{|c|}{ \# of Stones Retained } \\
\cline { 2 - 4 } & Tudlik & \multicolumn{1}{|c|}{ Kayuu } & \multicolumn{1}{c|}{ Naturalik } \\
\hline 1.18 & 0 & 1 & 0 \\
\hline 0.85 & 0 & 2 & 2 \\
\hline 0.6 & 2 & 2 & 1 \\
\hline 0.425 & 5 & 23 & 6 \\
\hline 0.3 & 12 & 37 & 17 \\
\hline 0.212 & 10 & 72 & 41 \\
\hline 0.15 & 29 & 113 & 57 \\
\hline 0.106 & 17 & 148 & 82 \\
\hline 0.075 & 31 & 169 & 108 \\
\hline Total Stones & 106 & 567 & 314 \\
\hline Weight (kg) & 89 & 791 & 713 \\
\hline
\end{tabular}

\section{Discussion and Conclusions}

A new diamondiferous kimberlite cluster was discovered at Nanuq in 2007. The three kimberlites found indicate that the area has the potential to host large pipes with significant tonnages and diamond contents. Careful geological work at the early stage of evaluating these bodies has shown that various phases within a single pipe have different diamond contents. This illustrates the importance of developing a good understanding of the geology of a kimberlite pipe at an early stage in its exploration and evaluation.

Unsourced kimberlite indicator mineral trains and untested high priority geophysical anomalies are present on the property and future exploration is anticpated to lead to the discovery of additional kimberltie pipes.

The kimberlites at Nanuq are unique in the Western Chrurchill Province in that they represent the first reported occurrene of crater-facies volcaniclastic and resedimented volcaniclastic kimberlites and record the first evidence of pre-existing Cretaceous sediments in this region (Webb et. al., this volume). They are also unique with respect to their ages (late Cretaceous, Campian to Maastrichtian) and are the youngest kimberlites documented in the area.

\section{Acknowledgements}

The base map for Figure 1 was kindly provided by Rob Berman of the Geological Survey of Canada.

\section{References}

Berman, R.G., Davis, W.J. and Pehrsson, S., 2007. Collisional Snowbird tectonic zone resurrected: Growth of Laurentia during the 1.9 GA accretionary phase of the Hudsonian orogeny; Geology, v. 35 no. 10, pp. 911-914.

Berman, R.G., Sanborn-Barrie, M., Stern, R., and Carson, C.J., 2005. Tectonometamorphism at ca. 2.35 and $1.85 \mathrm{Ga}$ in the Rae Domain, Western Churchill Province, Nunavut, Canada: Insights from structural, metamorphic and in situ geochronological analysis of the southwestern Committee Bay Belt; The Canadian Mineralogist, V. 43, pp. 409-442.

Card, K.D., Sanford, B.V. and Card, G.M., 1997. Controls on the Emplacement of Kimberlites and Alkalic Rockcarbonatite Complexes in the Canadian Shield and Surrounding Regions; Exploration and Mining Geology, Volume 6, Number 4, pp. 285-296.

Dredge, L.A. and McMartin, I., 2007. Surficial geology, Wager Bay, Nunavut; Geological Survey of Canada "A" Series Map 2111A; 1 sheet.

Dredge, L.A., McMartin, I., and Kjarsgaard, I.M.., 2006. Kimberlite indicator minerals in till from the Wager Bay area, mainland Nunavut: data and interpretation (NTS 56G); Geological Survey of Canada Open File 5087; 48p.

Panagapko, D.A, Pehrsson, S., Pilkington, M., and Currie, M., 2003. Geoscience data compilation Tehery Lake - Wager Bay Area, Nunavut, NTS 56B, C, F, and G. Part 1 - Data base themes. Geological Survey of Canada Open File 1809, scale: 1:250,000

Webb, K., Harder, M., Holmes, P., Baumgartner, M.C. and Pell., J., this volume. The geology of the Nanuq kimberlites: new textural varieties in the Western Churchill Province, Canada. 9IKC Extended Abstracts. 